\title{
The Life of Benjamin Franklin volume 3
}




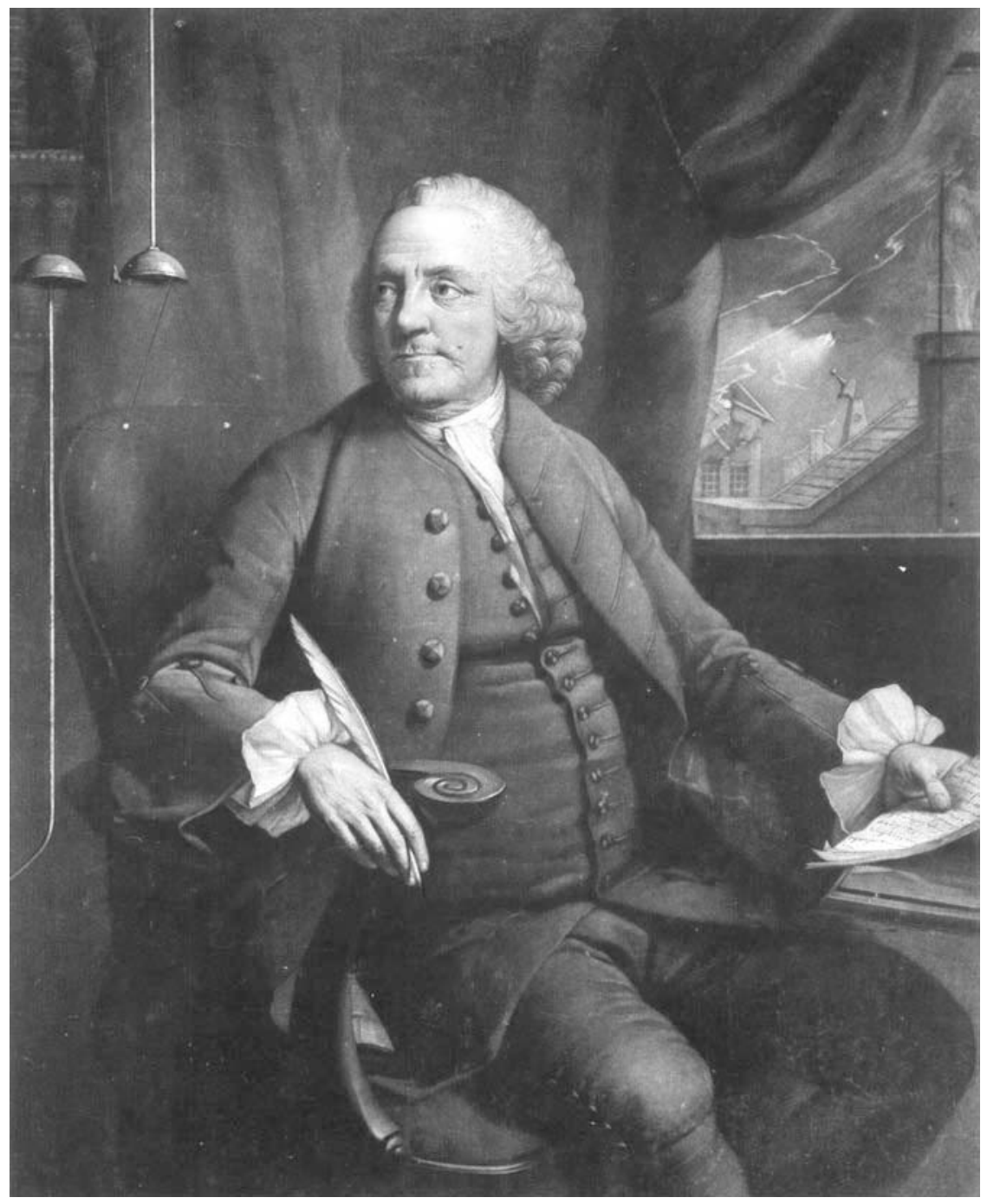


The Life of

Benjamin Franklin

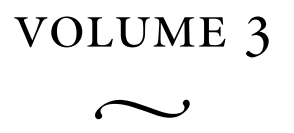

Soldier, Scientist,

and Politician

1748-1757

J. A. Leo Lemay

\section{$\overline{\text { PENN }}$}

University of Pennsylvania Press

Philadelphia 
Copyright (C) 2009 University of Pennsylvania Press

All rights reserved. Except for brief quotations used for purposes of review or scholarly citation, none of this book may be reproduced in any form by any means without written permission from the publisher.

Published by

University of Pennsylvania Press

Philadelphia, Pennsylvania 19104-4112

Printed in the United States of America on acid-free paper

$\begin{array}{llllllllll}10 & 9 & 8 & 7 & 6 & 5 & 4 & 3 & 2 & 1\end{array}$

Library of Congress Cataloging-in-Publication Data

Lemay, J. A. Leo (Joseph A. Leo), 1935-

The life of Benjamin Franklin / J. A. Leo Lamay.

p. $\mathrm{cm}$.

Includes bibliographical references and index.

Contents: v. 1. Journalist, $1706-1730-v$. 2. Printer and publisher, $1730-1747-v .3$.

Soldier, scientist, and politician, 1748-1757

ISBN 0-8122-3854-o (v. 1 : acid-free paper).-ISBN 0-8122-3855-9 (v. 2 : acid-free paper).--ISBN 978-0-8122-4121-1 (v. 3 : acid-free paper)

1. Franklin, Benjamin, 1706-1790. 2. Statesmen-United States-Biography.

3. Scientists-United States-Biography. 4. Inventors-United States-Biography.

5. Printers-United States-Biography. I. Title.

E302.6.F8L424 2005

$973.3^{\prime} 92-\mathrm{dc2} 2$

[B]

2004063130

Frontispiece: Benjamin Franklin, mezzotint by Edward Fisher after Mason

Chamberlain. Courtesy, National Portrait Gallery.

Endpapers: Map of Franklin's Philadelphia with key places of interest indicated. Reprinted from The Papers of Benjamin Franklin, ed. Leonard W. Labaree et al. (New Haven, Conn.: Yale University Press, 1959-), vol. 2, facing p. 456. Courtesy, Ellen R. Cohn. 
The biography as a whole is dedicated to

Ann C. Lemay, John C. Lemay, Kelly and Lee C. Lemay, and Kate C. Lemay

This volume is for Carla Mulford and David S. Shields, who were aided and abetted by A. Owen Aldridge, Robert D. Arner, Ralph Bauer, Pattie Cowell, Wayne Craven, Thomas J. Haslam, James Egan, Armin Paul Frank, Roy

Goodman, James Green, Kevin J. Hayes, Bernard Herman, Susan Clair Imbarrato, Robert Micklus, Barbara B. Oberg, Daniel Royot, Gordon M. Sayre, Karen N. Schramm, John Seelye, Nanette G. Tamer, Frank Shuffelton, Susan M. Stabile, Leonard Tennenhouse, and Paul M. Zall. 
